IZA DP No. 9949

Work Experience from Paid Employment and the Path to Entrepreneurship: Business Takeover versus New Venture Start-Up

Guoqian Xi Jörn Block

Frank Lasch

Frank Robert

Roy Thurik

May 2016 


\section{Work Experience from Paid Employment and the Path to Entrepreneurship: Business Takeover versus New Venture Start-Up}

\author{
Guoqian Xi \\ University of Trier \\ Jörn Block \\ University of Trier and \\ Erasmus University Rotterdam \\ Frank Lasch \\ Montpellier Business School
}

\author{
Frank Robert \\ Montpellier Business School
}

\author{
Roy Thurik \\ Erasmus University Rotterdam, \\ Montpellier Business School and IZA
}

Discussion Paper No. 9949
May 2016

IZA

P.O. Box 7240

53072 Bonn

Germany

Phone: +49-228-3894-0
Fax: +49-228-3894-180
E-mail: iza@iza.org

Any opinions expressed here are those of the author(s) and not those of IZA. Research published in this series may include views on policy, but the institute itself takes no institutional policy positions. The IZA research network is committed to the IZA Guiding Principles of Research Integrity.

The Institute for the Study of Labor (IZA) in Bonn is a local and virtual international research center and a place of communication between science, politics and business. IZA is an independent nonprofit organization supported by Deutsche Post Foundation. The center is associated with the University of Bonn and offers a stimulating research environment through its international network, workshops and conferences, data service, project support, research visits and doctoral program. IZA engages in (i) original and internationally competitive research in all fields of labor economics, (ii) development of policy concepts, and (iii) dissemination of research results and concepts to the interested public.

IZA Discussion Papers often represent preliminary work and are circulated to encourage discussion. Citation of such a paper should account for its provisional character. A revised version may be available directly from the author. 


\section{ABSTRACT \\ Work Experience from Paid Employment and the Path to Entrepreneurship: Business Takeover versus New Venture Start-Up*}

Our paper investigates how the type of work experience gained from prior paid employment influences the path to entrepreneurship. We distinguish between two distinct entrepreneurship entry modes: business takeover and new venture start-up. Using a large and rich French data set, we find that small firm experience increases the likelihood for business takeover, whereas management and same sector experience both increase the likelihood for new ventures. Our findings are relevant for policymakers aiming to improve the business transfer process.

JEL Classification: L26

Keywords: entrepreneurship entry mode, business takeover, new venture start-up, work experience

Corresponding author:

Roy Thurik

Erasmus School of Economics

Erasmus University Rotterdam

P.O. Box 1728

3000 DR Rotterdam

The Netherlands

E-mail: thurik@ese.eur.nl

\footnotetext{
* Frank Lasch, Frank Robert and Roy Thurik are members of the 'Entrepreneurship and Innovation' chair which is part of LabEx Entrepreneurship (University of Montpellier, France) and funded by the French government (Labex Entreprendre, ANR-10-Labex- 11-01). Guoqian Xi has received a scholarship from the China Scholarship Council.
} 


\section{Introduction}

There are several ways to become an entrepreneur; two distinct methods are either starting a new venture or taking over an existing business. Due to uncertainties related to newness and smallness, the new venture path is more risky than business takeover (Block et al., 2013; Parker and van Praag, 2012). The latter also requires more financial capital (Bastié et al., 2013). Prior research shows that several individual and country-specific characteristics influence the business takeover versus new venture decision (Bastié et al., 2013; Block et al., 2013; Parker and van Praag, 2012). So far, however, we know little about how the type of work experience from one's previous paid employment influences their path to entrepreneurship.

It has been shown that small firm and same sector experience influence the entrepreneurship decision (Elfenbein et al., 2010; Gompers et al., 2005; Parker, 2009). However, to date, this literature does not distinguish between different modes of entry into entrepreneurship. Our paper makes this distinction by analysing which type of work experience favours the business takeover or the new venture path.

Using a French firm-level data set, which includes more than 30,000 firms that were either started as new ventures or were taken over by an entrepreneur, we observe that the profiles of these two business types differ significantly in terms of the entrepreneur's work experience, education, growth ambition, age, and financial capital used. Most importantly, we find that small firm experience from previous paid employment increases the likelihood for business takeover, whereas management and same sector experience both increase the likelihood for new ventures.

Our paper contributes to the literature about the determinants of the path to entrepreneurship (Bastié et al., 2013; Block et al., 2013; Cooper and Dunkelberg, 1986; Fujii and Hawley, 1991; Parker and van Praag, 2012). We show how the type of work experience from previous paid employment influences whether new venture start-up or business takeover is used as entrepreneurship entry mode. Our finding that small firm experience favours business takeover has policy implications. Policymakers aiming to increase the match between firms looking for an outside successor and entrepreneurs willing to take over an established firm should target their efforts towards employees from small, rather than large firms. Our paper also contributes to the literature about the effects of work experience on the entrepreneurship decision (Elfenbein et al., 2010; Gompers et al., 2005; Parker, 2009) by distinguishing between different entrepreneurship entry modes.

\section{Dataset and variables}

Our dataset is called SINE (Système d'Information sur les Nouvelles Entreprises). It was created by INSEE (Institut National de la Statistique et des Etudes Economiques), which sent a questionnaire to all new ventures and business takeovers in France that were established in the first 
half of 2002. A total of 92,966 out of 100,731 firms responded to the questionnaire. This high response rate is due to SINE's mandatory nature and ensures that our dataset is representative for the French population of new ventures and business takeovers.

We restricted our sample to new ventures founded by or businesses that were taken over by former paid employees. We excluded former self-employed individuals, students, homemakers, retirees and unemployed individuals (39,567 individuals in total). Finally, we also excluded 11,284 part-time entrepreneurs.

The SINE data set includes three types of business takeovers: family firm takeovers, management buyouts, and outside takeovers. In line with prior research (Bastié et al., 2013; Parker and van Praag, 2012), we excluded 531 family firm takeovers and 803 management buyouts from our analysis, as these two types of takeovers constitute special cases that are not available for non-family members or external employees, respectively. Furthermore, outliers (eleven new ventures and takeovers with more than 200 employees) and observations with missing values are excluded from the sample. Our final sample consists of 30,756 full-time entrepreneurs (27,145 started a new venture, and 3,611 took over an existing business).

We run a logistic regression to conduct the analysis. Our dependent variable - business takeover - equals one if the entrepreneur chose business takeover as the entry mode and equals zero if the entrepreneur chose new venture start-up. Our focal independent variables concern the entrepreneur's previous work experience during paid employment. The variable management experience measures whether the entrepreneur has worked as a CEO or senior manager. The variable same sector experience equals one if the entrepreneur has worked in the same sector. We distinguish between three types of experience regarding firm size: small firm (less than 49 employees), medium firm (50 to 249 employees), and large firm experience (more than 250 employees).

We add several individual-level control variables, such as educational level, entrepreneurs in close relational circle, entrepreneurial training, growth ambition, age, gender, and nationality. Additionally, we control for firm-level characteristics such as the amount of start-up capital received, public aid, and percentage of self-funding. We also include nine industry and 26 region dummies as controls. All variables are defined in Table A1 of the appendix.

\section{Results}

About $88 \%$ of the entrepreneurs in our sample started a new venture; $12 \%$ chose business takeover. Table 1 compares entrepreneurs who started a new venture with entrepreneurs who chose business takeover as entry mode. We find that small firm experience is higher for entrepreneurs who chose business takeover than for entrepreneurs who started a new venture, whereas same sector experience is higher for new ventures than for business takeovers. The proportion of entrepreneurs with management experience is also higher for new ventures than for business takeovers. 
Table A2 of the appendix shows a correlation table and reports variance inflation factors (VIFs). The correlations between the independent variables are low and the VIFs fall within an acceptable range; as such, multicollinearity is unlikely to be a concern, particularly since the sample is very large. Table 2 shows the estimates of our logistic regression with business takeover as the dependent variable. The results show that the amount of start-up capital is positively associated with business takeover as the entrepreneurship entry mode. Moreover, the regressions confirm the univariate findings that new ventures are more likely to have received public aid and have a higher percentage of self-funding than business takeovers. Regarding individual-level control variables, we find that entrepreneurs with higher education are more likely to start a new venture, which corresponds to the results of Bastié et al. (2013), Block et al. (2013), and Parker and van Praag (2012). Furthermore, our results show that entrepreneurial training or having entrepreneurs in a close relational circle both have a positive relationship with new ventures. We also find that significant age effects exist: entrepreneurs aged 50 years and older prefer new ventures versus business takeovers. We did not find significant effects regarding gender or nationality.

With respect to our main independent variables, our results show that the firm size of the former employer matters. Compared to paid employees from small firms, employees from medium firms (medium firm experience: $\beta=-0.18, p<0.05$ ) and large firms (large firm experience: $\beta=-0.16, p<0.05$ ) are more likely to choose new venture start-up versus business takeover. In line with Bastié et al. (2013), we find that entrepreneurs with same sector experience are more likely to have entered entrepreneurship with a new venture than through business takeover $(\beta=-0.21, p<0.001)$. Management experience is positively related to new venture start-up $(\beta=-0.63, p<0.001)$. This finding differs from Bastié et al. (2013) and Parker and van Praag (2012).

We performed several robustness checks, of which the three most important are available in the appendix (Tables A3 and A4). In the first robustness check, we include 9,226 part-time entrepreneurs in our sample; in the second robustness check, we change the definition of management experience so that it only includes those entrepreneurs with senior management experience; in the third robustness check, we subdivide small firm (less than 49 employees) into micro firm (less than 10 employees) and small firm experience (10-49 employees). The results of the robustness checks confirm the findings from our main models. 


\section{Discussion and conclusion}

Our study shows that the type of work experience from previous paid employment influences the path to entrepreneurship and the choice of entrepreneurship entry mode. We distinguish between new venture start-up and business takeover as two important and common entrepreneurship entry modes. The existing literature on entrepreneurship choice regarding these two entry modes is still small (Bastié et al., 2013; Block et al., 2013; Parker and van Praag, 2012). Bastié et al. (2013) showed that entrepreneurs with social capital, higher educational level, and same sector experience favoured new venture start-up, whereas entrepreneurs with management experience preferred business takeover. Parker and van Praag (2012) found the same relationship as Bastié et al. (2013) regarding the relationship between management experience and business takeover; however, they did not find a significant effect of sector experience. Block et al. (2013) showed that the entrepreneur's educational level, risk attitude, and inventiveness are all positively associated with new venture start-up and that substantial cross-country differences exist in the preferred entry mode.

Our paper connects the small amount of literature regarding new venture start-up versus business takeover with the literature on how the type of work experience influences entrepreneurship entry modes (Elfenbein et al., 2010; Gompers et al., 2005; Parker, 2009). We find that small firm experience is positively associated with business takeover, whereas management experience and same sector experience exhibit negative relationships.

The small firm effect can be explained by the employees' reasons for leaving their paid employment to become entrepreneurs. We argue that the motivation to become an entrepreneur differs between paid employees from large versus small firms. Large firms tend to be hierarchical and bureaucratic. Employees may have felt frustrated that their former (large) employer neglected their innovative ideas. A well-documented example is Xerox; many former employees have founded small independent firms because Xerox rejected their innovative projects (Audretsch, 2007). In moving from paid employment to entrepreneurship, employees seek to realize their innovative ideas and become their own boss, giving them the possibility to create and shape their own organization and work environment (van Gelderen and Jansen, 2006). Because employees from large firms are often well paid and the opportunity costs are thus higher, we argue that, particularly for employees from large firms, non-financial aspects of entrepreneurship must play an important role in the motivation to become an entrepreneur (Millán et al., 2013). The importance of non-financial motivations, however, also varies according to one's career stage and family situation (Jaouen and Lasch, 2015; Jayawarna et al., 2011). In line with Block et al. (2013), we posit that the potential for innovation and the possibility to create one's own organization and work environment is greater in a new venture than a business takeover. By starting a new business from scratch, entrepreneurs can shape the venture to be exactly as they envision it. This possibility exists to a lesser extent with 
business takeovers, where the organization is already in place, including its products, employees, suppliers, and customers. Small firm employees, on the other hand, have had the opportunity to network with suppliers, customers, and even competitors. They are more adept and are in a better position at spotting potential high growth firms that are seeking outside successors, in particular micro and other small firms. Small firm employees may also be better suited to use their networks to acquire such firms.

We also show (see Table 2) that the profiles of those individuals starting new ventures versus those taking over existing businesses differ significantly in terms of work experience, education, ambition, age, and financial capital.

Our findings are relevant for policymakers aiming to improve the business transfer process. Across the EU and many other countries, several proposals have been made and initiatives have been launched that are designed to improve the business transfer process, including a reduction of (inheritance) taxes, measures to help prepare those who want to sell their business, as well as training and financial support for those who want to take over an existing business (European Commission, 2012). Our findings suggest that policymakers and firms looking for an outside successor should direct their efforts towards employees from small, rather than large firms.

Our study is not without limitations, from which avenues for further research can be identified. In particular, the type of work experience from paid employment investigated in this study could be extended to include experience from specific types of organizations, for instance, international firms or non-profit organizations. The number of years of general work experience may also play a role in explaining entrepreneurship choice (Fujii and Hawley, 1991). In addition, work experience can be categorized according to its specialized areas, such as marketing experience, R\&D experience, etc. (Stuetzer et al., 2012). Another promising avenue of future research is to look at how a balanced set of skills and experiences (Åstebro and Thompson, 2011; Lazear, 2005) may affect the path to entrepreneurship.

\section{References}

Åstebro, T., Thompson, P., 2011. Entrepreneurs, jacks of all trades or hobos? Res. Policy 40, 637649.

Audretsch, D.B., 2007. The Entrepreneurial Society. Oxford University Press, Oxford.

Bastié, F., Cieply, S., Cussy, P., 2013. The entrepreneur's mode of entry: the effect of social and financial capital. Small Bus. Econ. 40, 865-877.

Block, J., Thurik, R., van der Zwan, P., Walter, S., 2013. Business takeover or new venture? Individual and environmental determinants from a cross-country study. Entrep. Theory Pract. $37,1099-1121$. 
Cooper, A.C., Dunkelberg, W.C., 1986. Entrepreneurship and paths to business ownership. Strateg. Manag. J. 7, 53-68.

Elfenbein, D.W., Hamilton, B.H., Zenger, T.R., 2010. The small firm effect and the entrepreneurial spawning of scientists and engineers. Manage. Sci. 56, 659-681.

European Commision, 2012. Facilitating Transfer of Business.

http://bookshop.europa.eu/en/facilitating-transfer-of-business-pbNBBN12003/ (accessed 16.04.16).

Fujii, E.T., Hawley, C.B., 1991. Empirical aspects of self-employment. Econ. Lett. 36, 323-329.

Gompers, P., Lerner, J., Scharfstein, D., 2005. Entrepreneurial spawning: public corporations and the genesis of new ventures, 1986 to 1999 . J. Finance 60, 577-614.

Jaouen, A., Lasch, F., 2015. A new typology of micro-firm owner-managers. Int. Small Bus. J. 33, $397-421$.

Jayawarna, D., Rouse, J., Kitching, J., 2011. Entrepreneur motivations and life course. Int. Small Bus. J. 31, 34-56.

Lazear, E.P., 2005. Entrepreneurship. J. Labor Econ. 23, 649-680.

Millán, J.M., Hessels, J., Thurik, R., Aguado, R., 2013. Determinants of job satisfaction: a European comparison of self-employed and paid employees. Small Bus. Econ. 40, 651-670.

Parker, S.C., 2009. Why do small firms produce the entrepreneurs? J. Socio. Econ. 38, 484-494.

Parker, S.C., van Praag, C.M., 2012. The entrepreneur's mode of entry: Business takeover or new venture start? J. Bus. Ventur. 27, 31-46.

Stuetzer, M., Goethner, M., Cantner, U., 2012. Do balanced skills help nascent entrepreneurs to make progress in the venture creation process? Econ. Lett. 117, 186-188.

van Gelderen, M., Jansen, P., 2006. Autonomy as a start-up motive. J. Small Bus. Enterp. Dev. 13, $23-32$. 


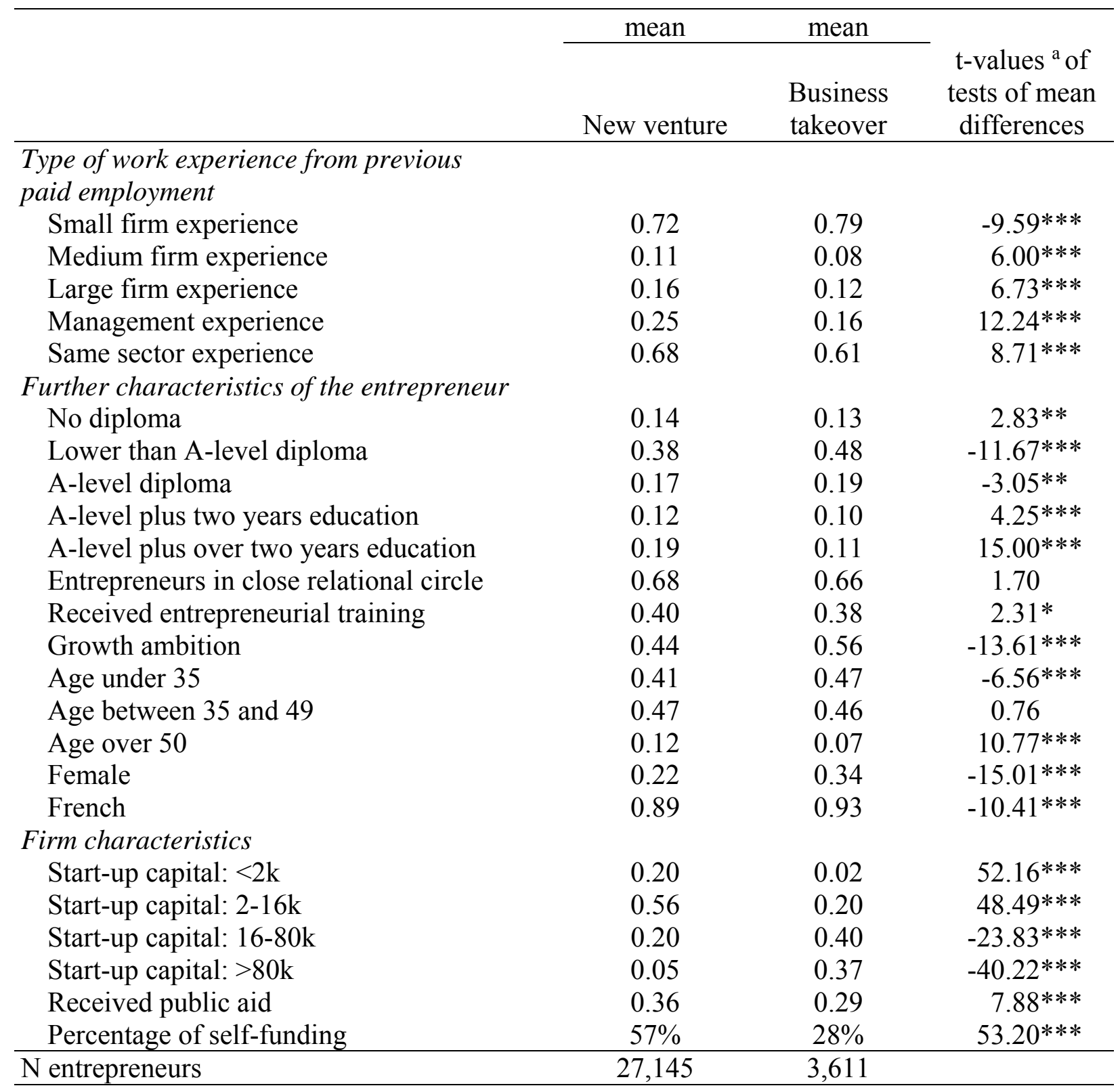

$* \mathrm{p}<0.05, * * \mathrm{p}<0.01, * * * \mathrm{p}<0.001$

a Welch's t-test 
Table 2: Logistic regression:

determinants of business takeover $($ dummy $=1)$ versus new venture start-up (dummy=0)

\begin{tabular}{|c|c|c|}
\hline & Coefficients & p-values \\
\hline \multicolumn{3}{|l|}{ Type of work experience from previous } \\
\hline Small firm experience & \multicolumn{2}{|c|}{ benchmark } \\
\hline Medium firm experience & -0.18 & 0.032 \\
\hline Large firm experience & -0.16 & 0.036 \\
\hline Management experience & -0.63 & 0.000 \\
\hline Same sector experience & -0.21 & 0.000 \\
\hline \multicolumn{3}{|l|}{ Control variables } \\
\hline \multicolumn{3}{|l|}{ Individual-level variables } \\
\hline No diploma & \multicolumn{2}{|c|}{ benchmark } \\
\hline Lower than A-level diploma & 0.07 & 0.357 \\
\hline A-level diploma & -0.23 & 0.008 \\
\hline A-level plus two years education & -0.39 & 0.000 \\
\hline A-level plus over two years education & -0.21 & 0.051 \\
\hline Entrepreneurs in close relational circle & -0.25 & 0.000 \\
\hline Received entrepreneurial training & -0.20 & 0.000 \\
\hline Growth ambition & 0.09 & 0.078 \\
\hline Benchmark: age under 35 & \multicolumn{2}{|c|}{ benchmark } \\
\hline Age between 35 and 49 & -0.01 & 0.900 \\
\hline Age over 50 & -0.21 & 0.022 \\
\hline Female & -0.05 & 0.358 \\
\hline French & -0.02 & 0.862 \\
\hline \multicolumn{3}{|l|}{ Firm-level variables } \\
\hline Start-up capital: $<2 \mathrm{k}$ & \multicolumn{2}{|c|}{ benchmark } \\
\hline Start-up capital: $2-16 \mathrm{k}$ & 1.23 & 0.000 \\
\hline Start-up capital: $16-80 \mathrm{k}$ & 2.50 & 0.000 \\
\hline Start-up capital: $>80 \mathrm{k}$ & 3.65 & 0.000 \\
\hline Received public aid & -0.74 & 0.000 \\
\hline Percentage of self-funding & -1.20 & 0.000 \\
\hline Industry dummies (9 categories) & Yes & 0.000 \\
\hline Region dummies ( 26 categories) & Yes & 0.000 \\
\hline Constant & -4.21 & 0.000 \\
\hline $\mathrm{N}$ entrepreneurs & 30,756 & \\
\hline McFadden's pseudo $\mathrm{R}^{2}$ & 0.46 & \\
\hline Log likelihood & $-5,959.45(\mathrm{p}<0.001)$ & \\
\hline Percentage correctly classified & $91.64 \%$ & \\
\hline
\end{tabular}




\section{Data brief and robustness checks}

\section{Table A1: Description of variables}

\begin{tabular}{|c|c|}
\hline Variable & Description \\
\hline \multicolumn{2}{|l|}{ Dependent variable } \\
\hline Business takeover & $\begin{array}{l}\text { Dummy }=1 \text { if the entrepreneur has taken over a firm from outside; dummy }=0 \text { if } \\
\text { the entrepreneur has started a new venture }(Q 5 / 7 / 17) \text {. }\end{array}$ \\
\hline \multicolumn{2}{|l|}{$\begin{array}{l}\text { Type of work experience from } \\
\text { previous paid employment }\end{array}$} \\
\hline Small firm experience & $\begin{array}{l}\text { Dummy }=1 \text { if the entrepreneur has work experience gained mainly from firm(s) } \\
\text { with less than } 50 \text { employees (Q9). }\end{array}$ \\
\hline Medium firm experience & $\begin{array}{l}\text { Dummy }=1 \text { if the entrepreneur has work experience gained mainly from firm(s) } \\
\text { with } 50 \text { to } 249 \text { employees (Q9). }\end{array}$ \\
\hline Large firm experience & $\begin{array}{l}\text { Dummy }=1 \text { if the entrepreneur has work experience gained mainly from firm(s) } \\
\text { with over } 250 \text { employees (Q9). }\end{array}$ \\
\hline Management experience & $\begin{array}{l}\text { Dummy }=1 \text { if the entrepreneur has worked as a CEO or senior manager before } \\
(\mathrm{Q} 5 / 6) \text {. }\end{array}$ \\
\hline Same sector experience & Dummy $=1$ if the entrepreneur has worked in the same sector before (Q10). \\
\hline \multicolumn{2}{|l|}{ Control variables } \\
\hline \multicolumn{2}{|l|}{ Individual-level variables } \\
\hline Benchmark: no diploma & Dummy $=1$ if the entrepreneur has no diploma (Q4). \\
\hline Lower than A-level diploma & Dummy $=1$ if the entrepreneur has lower than A-level diploma (Q4). \\
\hline A-level diploma & Dummy $=1$ if the entrepreneur has A-level diploma (Q4). \\
\hline A-level plus two years education & Dummy $=1$ if the entrepreneur has A-level diploma plus two years education (Q4). \\
\hline A-level plus over two years education & $\begin{array}{l}\text { Dummy }=1 \text { if the entrepreneur has A-level diploma plus more than two years } \\
\text { education }(\mathrm{Q} 4) \text {. }\end{array}$ \\
\hline Entrepreneurs in close relational circle & $\begin{array}{l}\text { Dummy }=1 \text { if the entrepreneur has business leaders or self-employed people in his } \\
\text { or her close relational circle (Q12). }\end{array}$ \\
\hline Received entrepreneurial training & $\begin{array}{l}\text { Dummy }=1 \text { if the entrepreneur has received specific training for his or her business } \\
(\mathrm{Q} 21) \text {. }\end{array}$ \\
\hline Growth ambition & $\begin{array}{l}\text { Dummy }=1 \text { if the entrepreneur's primary goal is to develop his or her business; } \\
\text { dummy }=0 \text { if the primary goal is to ensure his or her own job (Q16). }\end{array}$ \\
\hline Age under 35 & Dummy $=1$ if the entrepreneur is less than 35 years old (Q1). \\
\hline Age between 35 and 49 & Dummy $=1$ if the entrepreneur is between 35 and 49 years old (Q1). \\
\hline Age over 50 & Dummy $=1$ if the entrepreneur is over 50 years old $(\mathrm{Q} 1)$. \\
\hline Female & Dummy $=1$ if the entrepreneur is female (Q2). \\
\hline French & Dummy $=1$ if the entrepreneur is French (Q3). \\
\hline \multicolumn{2}{|l|}{ Firm-level variables } \\
\hline Start-up capital: $<2 \mathrm{k}$ & Dummy $=1$ if the start-up capital is less than $2,000 €(Q 23)$ \\
\hline Start-up capital: $2-16 \mathrm{k}$ & Dummy $=1$ if the start-up capital is from $2,000 €$ to less than $16,000 €(Q 23)$ \\
\hline Start-up capital: $16-80 \mathrm{k}$ & Dummy $=1$ if the start-up capital is from $16,000 €$ to less than $80,000 €(Q 23)$. \\
\hline Start-up capital: $>80 \mathrm{k}$ & Dummy $=1$ if the start-up capital is more than $80,000 €(Q 23)$ \\
\hline Received public aid & Dummy $=1$ if the entrepreneur has received public aid (Q27). \\
\hline Percentage of self-funding & $\begin{array}{l}\text { The percentage of self-funding or funding from family or associate in the total } \\
\text { amount of start-up capital }(25)\end{array}$ \\
\hline \multicolumn{2}{|l|}{ Other control variables } \\
\hline Industry dummies & $\begin{array}{l}9 \text { industries: Agricultural food, non-agricultural food, construction, commerce, } \\
\text { transport, real estate, business services, personal services, education, health and } \\
\text { social work. The definition is based on French Classification of Activities (NAF) }\end{array}$ \\
\hline Region dummies & $\begin{array}{l}26 \text { regions: Alsace, Aquitaine, Auvergne, Basse-Normandie, Bourgogne, } \\
\text { Bretagne, Centre, Champagne-Ardenne, Corse, Franche-Comté, Guadeloupe, } \\
\text { Guyane, Haute-Normandie, Île-de-France, Languedoc-Roussillon, La Réunion, } \\
\text { Limousin, Lorraine, Martinique, Midi-Pyrénées, Nord-Pas-de-Calais, Pays de la } \\
\text { Loire, Picardie, Poitou-Charentes, Provence-Alpes-Côte d'Azur, Rhône-Alpes }\end{array}$ \\
\hline
\end{tabular}


Table A2: Correlation table

\begin{tabular}{|c|c|c|c|c|c|c|c|c|c|c|c|c|c|c|c|c|c|c|c|c|c|c|}
\hline & & 1 & 2 & 3 & 4 & 5 & 6 & 7 & 8 & 9 & 10 & 11 & 12 & 13 & 14 & 15 & 16 & 17 & 18 & 19 & 20 & VIF \\
\hline 1 & Business takeover & & & & & & & & & & & & & & & & & & & & & 1.31 \\
\hline 2 & Medium firm experience & -0.03 & & & & & & & & & & & & & & & & & & & & 1.07 \\
\hline 3 & Large firm experience & -0.04 & -0.15 & & & & & & & & & & & & & & & & & & & 1.18 \\
\hline 4 & Management experience & -0.06 & 0.10 & 0.20 & & & & & & & & & & & & & & & & & & 1.43 \\
\hline 5 & Same sector experience & -0.05 & -0.05 & -0.14 & -0.03 & & & & & & & & & & & & & & & & & 1.06 \\
\hline 6 & Lower than A-level diploma & 0.07 & -0.06 & -0.15 & -0.27 & 0.03 & & & & & & & & & & & & & & & & 2.50 \\
\hline 7 & A-level diploma & 0.02 & -0.02 & -0.01 & -0.02 & -0.03 & -0.36 & & & & & & & & & & & & & & & 2.02 \\
\hline 8 & A-level plus two years education & -0.02 & 0.07 & 0.07 & 0.04 & -0.05 & -0.29 & -0.16 & & & & & & & & & & & & & & 1.81 \\
\hline 9 & A-level plus over two years education & -0.07 & 0.09 & 0.25 & 0.42 & -0.03 & -0.38 & -0.21 & -0.17 & & & & & & & & & & & & & 2.44 \\
\hline 10 & Entrepreneurs in close circle & -0.01 & 0.00 & -0.02 & 0.01 & -0.01 & -0.01 & 0.03 & 0.02 & 0.00 & & & & & & & & & & & & 1.02 \\
\hline 11 & Received entrepreneurial training & -0.01 & -0.05 & -0.08 & -0.23 & 0.02 & 0.21 & 0.00 & -0.08 & -0.20 & 0.04 & & & & & & & & & & & 1.15 \\
\hline 12 & Growth ambition & 0.08 & 0.00 & -0.03 & 0.06 & 0.04 & -0.01 & 0.02 & 0.03 & -0.05 & 0.05 & 0.02 & & & & & & & & & & 1.10 \\
\hline 13 & Age between 35 and 49 & 0.00 & 0.04 & 0.02 & 0.04 & -0.03 & 0.07 & -0.05 & -0.05 & -0.02 & -0.03 & -0.02 & -0.02 & & & & & & & & & 1.20 \\
\hline 14 & Age over 50 & -0.05 & 0.03 & 0.12 & 0.21 & -0.04 & -0.05 & 0.01 & -0.02 & 0.09 & -0.07 & -0.12 & -0.10 & -0.34 & & & & & & & & 1.27 \\
\hline 15 & Female & 0.09 & -0.01 & 0.02 & -0.07 & -0.11 & -0.08 & 0.08 & 0.05 & 0.08 & 0.01 & -0.03 & -0.10 & 0.00 & -0.02 & & & & & & & 1.09 \\
\hline 16 & French & 0.05 & 0.04 & 0.07 & 0.07 & -0.11 & 0.06 & 0.07 & 0.07 & 0.06 & 0.07 & -0.02 & -0.04 & -0.03 & 0.03 & 0.10 & & & & & & 1.13 \\
\hline 17 & Start-up capital: 2-16k & -0.23 & -0.01 & -0.04 & -0.04 & 0.05 & 0.02 & -0.02 & 0.00 & -0.05 & 0.00 & 0.02 & -0.04 & 0.01 & 0.00 & -0.07 & -0.08 & & & & & 2.00 \\
\hline 18 & Start-up capital: $16-80 \mathrm{k}$ & 0.16 & 0.00 & 0.01 & 0.00 & -0.04 & 0.02 & 0.04 & 0.00 & -0.03 & 0.04 & 0.06 & 0.13 & 0.00 & -0.04 & 0.03 & 0.08 & -0.55 & & & & 2.06 \\
\hline 19 & Start-up capital: >80k & 0.38 & 0.00 & 0.04 & 0.12 & -0.04 & -0.04 & 0.00 & 0.02 & 0.07 & 0.02 & -0.03 & 0.13 & 0.01 & 0.00 & 0.02 & 0.04 & -0.32 & -0.16 & & & 1.75 \\
\hline 20 & Received public aid & -0.04 & -0.01 & -0.04 & -0.11 & -0.08 & 0.07 & 0.02 & 0.02 & -0.05 & 0.05 & 0.20 & 0.00 & 0.00 & -0.06 & 0.06 & 0.10 & 0.03 & 0.11 & -0.06 & & 1.11 \\
\hline 21 & Percentage of self-funding & -0.22 & 0.04 & 0.08 & 0.14 & -0.04 & -0.14 & -0.01 & 0.07 & 0.14 & -0.01 & -0.12 & -0.07 & 0.03 & 0.08 & -0.05 & -0.06 & 0.14 & -0.18 & -0.16 & -0.10 & 1.16 \\
\hline
\end{tabular}

$\mathrm{N}$ entrepreneurs $=30,756$. Correlation coefficients which are greater than or equal to 0.02 (in absolute value) are significant at $0.1 \%$ level. Mean VIF $=1.47$. 


\begin{tabular}{|c|c|c|}
\hline & $\begin{array}{l}\text { Robustness check I } \\
\text { (Part-time entrepreneurs are } \\
\text { included in the sample) }\end{array}$ & $\begin{array}{l}\text { Robustness check II } \\
\text { (Management experience is defined } \\
\text { as working as senior manager } \\
\text { before) }\end{array}$ \\
\hline \multicolumn{3}{|c|}{ Type of work experience from previous paid employment } \\
\hline \multicolumn{3}{|c|}{ Benchmark: small firm experience } \\
\hline \multirow[t]{2}{*}{ Medium firm experience } & $-0.13^{+}$ & $-0.22^{*}$ \\
\hline & $(-1.80)$ & $(-2.42)$ \\
\hline \multirow[t]{2}{*}{ Large firm experience } & $-0.15^{*}$ & $-0.25^{* *}$ \\
\hline & $(-2.32)$ & $(-3.17)$ \\
\hline \multirow[t]{2}{*}{ Management experience } & $-0.77^{* * *}$ & $-0.43^{* * *}$ \\
\hline & $(-12.84)$ & $(-4.79)$ \\
\hline \multirow[t]{2}{*}{ Same sector experience } & $-0.08^{+}$ & $-0.26^{* * *}$ \\
\hline & $(-1.81)$ & $(-4.87)$ \\
\hline \multicolumn{3}{|l|}{ Control variables } \\
\hline \multicolumn{3}{|l|}{ Individual-level variables } \\
\hline \multicolumn{3}{|l|}{ Benchmark: no diploma } \\
\hline \multirow[t]{2}{*}{ Lower than A-level diploma } & -0.06 & -0.01 \\
\hline & $(-0.84)$ & $(-0.12)$ \\
\hline \multirow[t]{2}{*}{ A-level diploma } & $-0.40^{* * *}$ & $-0.35^{* * *}$ \\
\hline & $(-5.19)$ & $(-3.74)$ \\
\hline \multirow[t]{2}{*}{ A-level plus two years education } & $-0.53^{* * *}$ & $-0.59^{* * *}$ \\
\hline & $(-5.90)$ & $(-5.35)$ \\
\hline \multirow[t]{2}{*}{ A-level plus over two years education } & $-0.43^{* * *}$ & $-0.38^{* *}$ \\
\hline & $(-4.77)$ & $(-3.23)$ \\
\hline \multirow[t]{2}{*}{ Entrepreneurs in close relational circle } & $-0.29^{* * *}$ & $-0.29^{* * *}$ \\
\hline & $(-6.39)$ & $(-5.38)$ \\
\hline \multirow[t]{2}{*}{ Received entrepreneurial training } & $-0.14^{* *}$ & $-0.23^{* * *}$ \\
\hline & $(-2.94)$ & $(-4.26)$ \\
\hline \multirow[t]{2}{*}{ Growth ambition } & 0.06 & 0.08 \\
\hline & (1.40) & (1.56) \\
\hline \multicolumn{3}{|l|}{ Benchmark: age under 35} \\
\hline \multirow[t]{2}{*}{ Age between 35 and 49} & -0.01 & -0.01 \\
\hline & $(-0.12)$ & $(-0.26)$ \\
\hline \multirow[t]{2}{*}{ Age over 50} & $-0.31^{* * *}$ & $-0.19^{+}$ \\
\hline & $(-3.89)$ & $(-1.85)$ \\
\hline Female & 0.07 & $-0.11^{*}$ \\
\hline & $(1.36)$ & $(-2.02)$ \\
\hline French & -0.11 & 0.02 \\
\hline & $(-1.30)$ & $(0.17)$ \\
\hline Firm-level variables & & \\
\hline Benchmark: start-up capital: $<2$ & & \\
\hline Start-up capital: 2-16k & $1.18^{* * *}$ & $1.27^{* * *}$ \\
\hline & $(10.50)$ & (9.27) \\
\hline Start-up capital: $16-80 \mathrm{k}$ & $2.45^{* * *}$ & $2.59^{* * *}$ \\
\hline & (21.87) & (18.95) \\
\hline Start-up capital: $>80 \mathrm{k}$ & $3.43^{* * *}$ & $3.80^{* * *}$ \\
\hline & (29.14) & (26.31) \\
\hline Received public aid & $-0.62^{* * *}$ & $-0.78^{* * *}$ \\
\hline & $(-12.75)$ & $(-14.30)$ \\
\hline Percentage of self-funding & $-1.14^{* * *}$ & $-1.23^{* * *}$ \\
\hline & $(-18.45)$ & $(-16.39)$ \\
\hline Industry dummies (9 categories) & $p<0.001$ & $p<0.001$ \\
\hline Region dummies ( 26 categories) & $p<0.001$ & $p<0.001$ \\
\hline Constant & $-3.73^{* * *}$ & $-3.97^{* * *}$ \\
\hline & $(-10.22)$ & $(-8.60)$ \\
\hline $\mathrm{N}$ entrepreneurs & 39,982 & 28,576 \\
\hline McFadden's pseudo $R^{2}$ & 0.430 & 0.478 \\
\hline Log likelihood & $-7,604.04$ & $-5,432.11$ \\
\hline $\operatorname{LR} \times 2$ & $11,477.76^{* * *}$ & $9,957.90^{* * *}$ \\
\hline Percentage correctly classified & $92.04 \%$ & $91.91 \%$ \\
\hline
\end{tabular}


Table A4: Robustness check III

Robustness check III

(Micro firm: less than 10 employees; small firm: 10-49 employees)

\begin{tabular}{|c|c|}
\hline Type of work experience from previous paic & \\
\hline Benchmark: micro firm experier & \\
\hline Small firm experience & $-0.11^{+}$ \\
\hline & $(-1.83)$ \\
\hline Medium firm experience & $-0.22^{*}$ \\
\hline & $(-2.54)$ \\
\hline Large firm experience & $-0.20^{*}$ \\
\hline & $(-2.54)$ \\
\hline Management experience & $-0.63^{* * *}$ \\
\hline & $(-8.77)$ \\
\hline Same sector experience & $-0.22^{* * *}$ \\
\hline & $(-4.17)$ \\
\hline Control variables & \\
\hline Individual-level variables & \\
\hline Benchmark: no diploma & \\
\hline Lower than A-level diploma & 0.07 \\
\hline & $(0.96)$ \\
\hline A-level diploma & $-0.23^{* *}$ \\
\hline & $(-2.62)$ \\
\hline A-level plus two years education & $-0.38^{* * *}$ \\
\hline & $(-3.66)$ \\
\hline A-level plus over two years education & $-0.21^{+}$ \\
\hline & $(-1.96)$ \\
\hline Entrepreneurs in close relational circle & $-0.25^{* * *}$ \\
\hline & $(-4.97)$ \\
\hline Received entrepreneurial training & $-0.20^{* * *}$ \\
\hline & $(-3.86)$ \\
\hline Growth ambition & $0.09^{+}$ \\
\hline & $(1.84)$ \\
\hline Benchmark: age under 35 & \\
\hline Age between 35 and 49 & -0.00 \\
\hline & $(-0.08)$ \\
\hline Age over 50 & $-0.21^{*}$ \\
\hline & $(-2.28)$ \\
\hline Female & -0.06 \\
\hline & $(-1.13)$ \\
\hline French & -0.01 \\
\hline & $(-0.14)$ \\
\hline Firm-level variables & \\
\hline Benchmark: Start-up capital: $<2$ & \\
\hline Start-up capital: 2-16k & $1.23^{* * *}$ \\
\hline & $(9.32)$ \\
\hline Start-up capital: $16-80 \mathrm{k}$ & $2.50^{* * *}$ \\
\hline & $(19.02)$ \\
\hline Start-up capital: >80k & $3.65^{* * *}$ \\
\hline & $(26.41)$ \\
\hline Received public aid & $-0.74^{* * *}$ \\
\hline & $(-14.04)$ \\
\hline Percentage of self-funding & $-1.20^{* * *}$ \\
\hline & $(-16.72)$ \\
\hline Industry dummies (9 categories) & $p<0.001$ \\
\hline Region dummies ( 26 categories) & $p<0.001$ \\
\hline Constant & $-4.17^{* * *}$ \\
\hline & $(-9.83)$ \\
\hline $\mathrm{N}$ entrepreneurs & 30,756 \\
\hline McFadden's pseudo $R^{2}$ & 0.46 \\
\hline Log likelihood & $-5,957.76$ \\
\hline $\operatorname{LR} \times 2$ & $10,335.12^{* * *}$ \\
\hline Percent correctly classified & $91.61 \%$ \\
\hline
\end{tabular}

Notes: $t$ statistics in parentheses. ${ }^{+} p<0.10,{ }^{*} p<0.05,{ }^{* *} p<0.01,{ }^{* * *} p<0.001$ 